\title{
ECOLOGICAL IMPORTANCE OF ELECTRICAL DEVICES INNOVATIVE IN THE PROCESS OF ANTI AMBROSIA ARTEMISIIFOLIA L
}

\author{
Miloš Stanković', Marïa Cvijanović2 ${ }^{2}$ Vojin Đukić3
}

\begin{abstract}
Summary
Large amounts of aerosols that linger in the atmosphere are becoming carriers of pollen. Ambrosia artemisiifolia $L$ has the ability to produce large amounts of pollen. Given the high adaptability of Ambrosia artemisiifolia $L$ for the dissemination of the big problem is its suppression. In practice, the most common method of combating Ambrosia is the use of different groups of herbicides which adversely affects the environment.

Therefore, the aim of the paper is set to investigate the efficacy of the treatment plant Ambrosia artemisiifolia L supply via innovative devices in the stage of development of vegetative growth of the plants after harvest of wheat. The first results were visible after only 20 minutes, and the total number of plants in the treatment was destroyed after 5 days.
\end{abstract}

Key words: Ambrosia artemisiifolia L, electrical voltage, current, resistance of plants JEL: $Q 57, Q 16$

\section{Introduction}

The sharp technical-technological development in order to improve the quality of life of people, brought many negative consequences in the environment. One of the main long-term result of climate change caused by increased concentration of carbon dioxide in the air.Climate change is a problem that the world faces today. According to data from the Intergovernmental Panel on Climate Change (IPCC 2007) increase in average annual air temperature by 2100 will be up to $6.4^{\circ} \mathrm{C}$, with uneven and unpredictable intensity of rainfall and storms that affect the changing conditions for life. Climate changes affect the survival of certain species of plants, the change in the number of species and subspecies, as well as the extension of the growing of some plant species.In addition to these changes occur intensified bioproduction alergijiskih plant species as well as the increased production of their pollen (Dechamp et al., 2002; Rogers et al., 2006). Increased concentration of pollen in the lower parts of the

1 Stanković Miloš, Ph.D. student, Alfa BK University, Faculty of Finance, Banking and Audit, Palmira Toljatija street no. 311000 Novi Beograd, Serbia +381 638579805 E-mail: milosstanko@yahoo.com

2 Cvijanović Marija, Ph.D. student, University of Belgrade, Faculty of Agriculture, Nemanjina Street no. 6, 11080 Zemun, Serbia, Phone: +381 6388581085 E-mail: marijacvijanovic@yahoo.com

3 Đukić Vojin Ph.D., Research Fellow, Institute of Field and Vegetable Crops in Novi Sad, Maksima Gorkog Street no. 30, 21000, Phone: +381 6482057 51, E-mail: vojin.djukic@ifvens.ns.ac.rs 
atmosphere withthe presence of aerosols create complexes that in humans cause major health problems (Wayne et al., 2002). These phenomena are characteristic of urban areas with a high concentration of aerosols, carbon dioxide in the air and increased air temperature. It is estimated that more than $10 \%$ of the population sensitive to pollen of plants, and that more than $50 \%$ of allergies caused by Ambrosia pollen. Allergic reactions caused by Ambrosia pollen can be a tragic end, and in a world where the weed mass present allocated large funds for its suppression and measuring the concentration of pollen in the air (HERBAL Society of Serbia 2007).One gram of pollen Ambrosia artemisiifolia L. contains up to 35 million pollen grains, and one plant can produce during the year to 1,350 million pollen grains (Fumanal, 2005). Therefore, this type of Ambrosia in the list of quarantine harmful organisms (S1. list SRJ br. 8/99). The Government of the Republic of Serbia passed a Decree on measures for the control and destruction of weed species (Sl. Glasnik br. 69/06).

Ambrosia is an invasive weed plant species that can be counted about 48 different species (Dëchamp i Mëon, 2003). Widespread is throughout the world according to Allard, (1973), occupies an area of 50 parallels the north to the 32 and 35 parallels the south. Seeds of Ambrosia was transferred from America to Europe where it spread with incredible speed, and today it is the most represented in the eastern and south-eastern part. In the western part of Europe is less frequent since increased humidity in this part of Europe is a limiting factor for its development.The most represented and distributed species Ambrosia artemisiifolia L. popularly known as "pelenasta" ambrosia. In Serbia, was first recorded in 1953 (Slavnić, 1953). The last 60 years ambrosia is spreading throughout the territory of Serbia. The spread of Ambrosia and survival, it is possible not only to a slight adaptation, but also the fact that in the process ambrosia loses its natural enemies (Maron et al., 2004). In addition ambrosia no great demand on physical, chemical properties of the soil. Observing the behavior of populations, noted the conquest of new spaces with natural vegetation, semi-closed, usually degraded meadow (Comtois, 1998). Wins habitats such as abandoned and unfinished land and arable land (Bohren at all., 2006). On the arable land is very well developed in the arable crops corn, sunflower, soybean and can reduce the yield of cultivated plants by $25-30 \%$ depending on its exuberance. Also, rapidly evolving surfaces after winter wheat.

All these are reasons that indicate that a program to combat Ambrosia should focus on reducing the number of plants that can produce seed. Thus, to combat Ambrosia was best done in the phase of vegetative growth before flowering.

\section{Literature Overview}

When it comes to large areas where ragweed is present, then agrotechnical and mechanical measures are not enough. One of the main ways to combat Ambrosia is the application of chemicals, especially herbicides. Herbicides are applied across the land (at the stage of germination Ambrosia) over the sheet (before flowering).However, there are big problems in controlling Ambrosia herbicides, and in terms of efficiency and in terms of environmental protection. The best results are achieved in the fight against Ambrosia is a mixture of different herbicides (Niekamp, Johnson, 2001). The effectiveness of herbicides depends on the stage 
of development Ambrosia and stages of development of cultivated crops.On the other hand all the more limited use of chemical agents on surfaces with cultivated plants, because of their specific retention in the ecosystem and the negative impact on the dynamics of the parameters of soil biogeny (Cvijanović et al., 2006).

For this reason, increasingly resorted to other measures in the fight against Ambrosia such as knowledge of biophysical sciences. Over the past few decades increasing number Researchers have tried using that particular voltage and current combat ragweed and other weeds. Research Mattsson (1995) on the use of devices with naponoma of $9 \mathrm{KV}$ to $13 \mathrm{KV}$, and the power of $50 \mathrm{KW}$ to $110 \mathrm{KW}$ show that they have some limitations but also to be used in the control of weed species.

In the last few decades, a growing number of researchers trying to using a certain voltage and current prevents the development of Ambrosia on arable land. Diprose et al. (1978) used the current effective value of $8.4 \mathrm{kV}$ voltage in the control of Ambrosia in crops of sugar beet. The tractor of $52 \mathrm{~kW}$ driven by the generator of $24 \mathrm{~kW}$ and $240 \mathrm{~V}$ rms who supplied transformer whereby been receiving $8.4 \mathrm{kV}$ rms value of the voltage at the output. The whole machine is able to move at a speed of $1.6 \mathrm{~km} / \mathrm{h}$ to give the contact a plantelectrode about 2 or 3 seconds. Treatments were repeated twice at an interval of four weeks. Of the 186 annual plants counted on an experimental plot, 51\% continued to grow after the treatment but did not produce usable seeds. Of the remainder, 24\% were destroyed leaves and stems and it was produced seed. $25 \%$ of those surviving plants were crop growth or even less so that the electrode is missed.

Therefore, the aim of the study is set to examine the possibility of suppression Ambrosia's patented device that is in the Department of patents RST/RS20015/000002. Unlike other electrical equipment for controlling weeds, the essence of this innovation makes use of thyristor switches, which is achieved simply putting the device into operation and achieved simpler regulation. The novelty of the device for controlling weeds, consists in the use of thyristor switch, connected via a voltage transformer with synthesizers, while the unit's power can be autonomously (using batteries or aggregate) or using the power grid (single phase or interphase). Novelty is also a use of a reverse link between the highvoltage transformer and voltage multiplier.

The essence of innovation consists in the fact that pressing the button closes the circuit of transformer primary which in his round secondary induced electromotive force is multiplied to the required high voltage using the voltage multiplier. Amplified and rectified voltage supplied by the primary high-voltage transformer, the feedback in the feedback branch of a high voltage induced in the secondary high-voltage transformer via electrodes at its output acts on harmful weed plants or their parts. In the event that the input voltage is unidirectional, then the button to close the circuit connected oscillator certain frequencies. 


\section{Methods}

The experiment was conducted during 2015 at the Agricultural Institute of Slovenia, the experimental field „Jable“, located in Domažale between Ljubljana and Kranj. In the experimental field, with an area of $50 \mathrm{~m}^{2}$ was a crop of wheat.

Ambrosia artemisiifolia L. was in the stage of vegetative growth to $30 \mathrm{~cm}$. For the control of Ambrosia using a device which carries a number of patentRST/RS20015/000002.

The examination procedure:

- Selected Ambrosia in the fields after the harvest of wheat on an area of $5 \mathrm{~m} \mathrm{x} 10 \mathrm{~m}$ (551 plants), a Ambrosia out of it were control;

- Some are the largest and smallest diameters of stem Ambrosia at the contact with the -electrode (i.e. 7 - $20 \mathrm{~cm}$ above the ground), and near the root;

- The stem of the plant is pressed horizontal electrode;

- The land is stung second electrode that has the grounding;

- Through the plant (in this case, for a period of 1.5 seconds) has failed current;

- After treatment, continues monitoring the situation for several days.

\section{Results and discussion}

Plants that are up to $30 \mathrm{~cm}$ in height, trunk diameter, about 5,073 $\pm 995 \mu \mathrm{m}$, a central part of the tree-filled parenchymal cells, the experiment is sufficient lower part of the stem of the plant. Therefore, the treatment plant was completed on the stem at the level of $7-20 \mathrm{~cm}$ of the soil surface. This part of the plant was exposed to a voltage of $25 \mathrm{kV}$, and the time ekspozijcije 1.5 seconds. An important parameter and a status indicator (and the degree of destruction) of the plant is its electrical resistance. How are from earlier tests can be concluded, as soon as through the plants originate an electric current of sufficient strength, its resistance to doing almost linearly decrease to a certain minimum value. This process is closely related to the degree of destruction of the plant, ie. the lower the resistance, the degree of destruction of the plant is higher. After reaching the minimum, resistance of the plants remain for some time about equal to this valu), and then begins to rise, possibly due to fluid loss caused by overheating of the plants above $100^{\circ} \mathrm{C}$. 
Figure 1. Schematic of galvanic connection

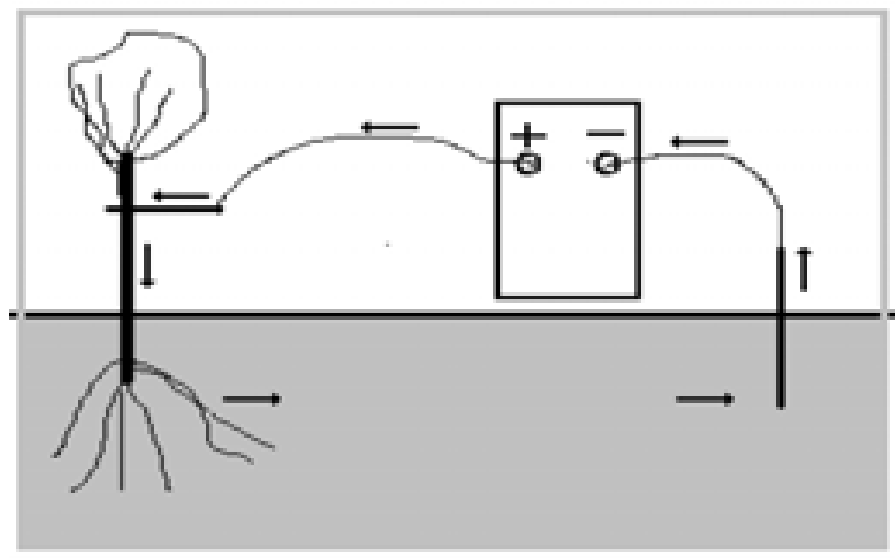

Source: authors, based on research

For complicated structure such as plant stems, specific resistance will be a function of all three spatial coordinates, however, in this case we could only come up to the equivalent specific resistance, tag it with $\rho$, whose formula:

$$
\rho=\frac{1}{4} \pi \frac{\mathrm{a}_{1} \mathrm{~b}_{2}-\mathrm{a}_{2} \mathrm{~b}_{1}}{h} \frac{1}{\ln \frac{\mathrm{a}_{1} \mathrm{~b}_{2}}{\mathrm{a}_{2} \mathrm{~b}_{1}}} \mathrm{R}
$$

where is: R- measured the resistance of a piece of the plant; $h$ - a stem length; $a_{1}, b_{1}, a_{2}, b_{2}$ double the length of the large and small axis of this cross section of the stem at its beginning and end.

Going through ambrosia, electricity produced voltages from $25 \mathrm{kV}$, left a visible trail of scorched. This phenomenon is easy to understand since it is about the classic places a short circuit in the electrical circuit, and in them, because of high resistance, releases the most energy per unit time.

Immediately after treatment, the stems of plants were a little heated (could stick your fingers) and retained the green color which, in our judgment, means that is in them, with the possible chemical changes, there was the process of "cooking" and not "roasting". When an electric current passes through the stalks of weeds, the weeds are happening biophysical and biochemical processes, after which the weeds veins (Stankovic, 2012). I mmediately after 2040 minutes were visible operating results of current flow through the plant (Fig. 2, 3).

Based on these results, two days after the treatment was destroyed $63 \%$ or 347 plants (Tab. 1). Other plants $204(37.0 \%)$ were partially retained the green color of leaves, while the lower part of the stems was dry. In the next three days preostelih 204 plants were completely dry, so after five days of treatment plants was not a single green plants Ambrosia. On the roof can be used only once (Stanković, 2014). 
Table 1. Dynamics of the number of plants at different time intervals after treatment current intensity $25 \mathrm{kV}$

\begin{tabular}{|c|c|c|c|c|c|c|}
\hline \multirow{2}{*}{$\begin{array}{c}\text { The total number of } \\
\text { plants } \\
\text { before treatment }\end{array}$} & \multicolumn{4}{|c|}{ Time after treatment (days) } & \multirow{2}{*}{\multicolumn{2}{|c|}{$\begin{array}{c}\text { The total number of plants } \\
\text { before treatment }\end{array}$}} \\
\hline & \multicolumn{2}{|c|}{2 days } & \multicolumn{2}{|c|}{5 days } & & \\
\hline \multirow{2}{*}{551} & Number & $\%$ & Number & $\%$ & Number & $\%$ \\
\hline & 347 & 62.9 & 204 & 37.0 & 551 & 100 \\
\hline
\end{tabular}

Source: authors, based on research

Figure 2. Appearance of plants Ambrosia artemisiifolia L. 20 minutes after treatment

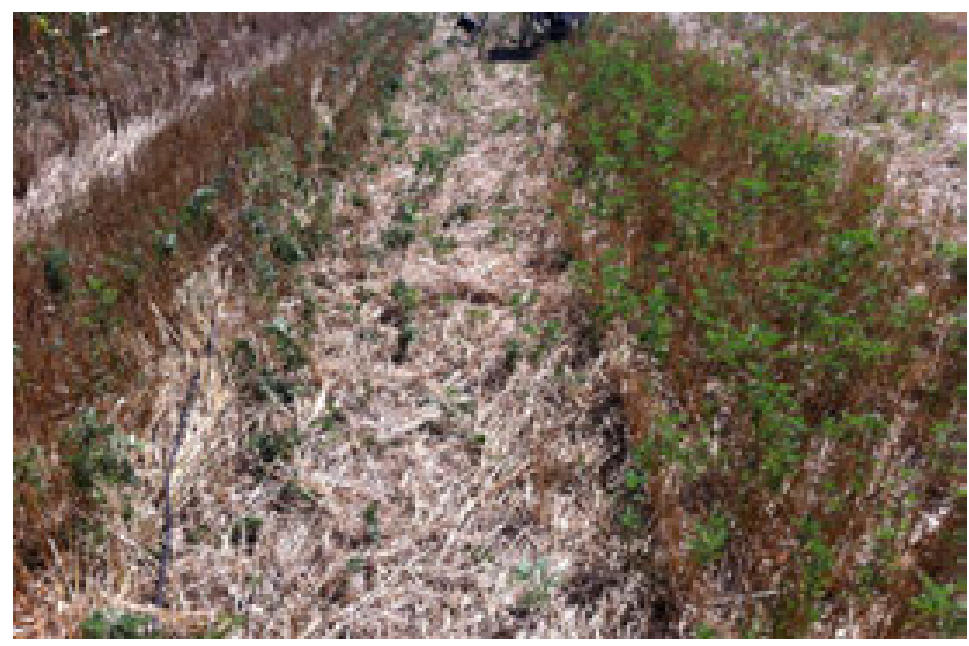

Source: authors, based on research

Figure 3. Appearance of plants Ambrosia artemisiifolia L. 40 minutes after treatment

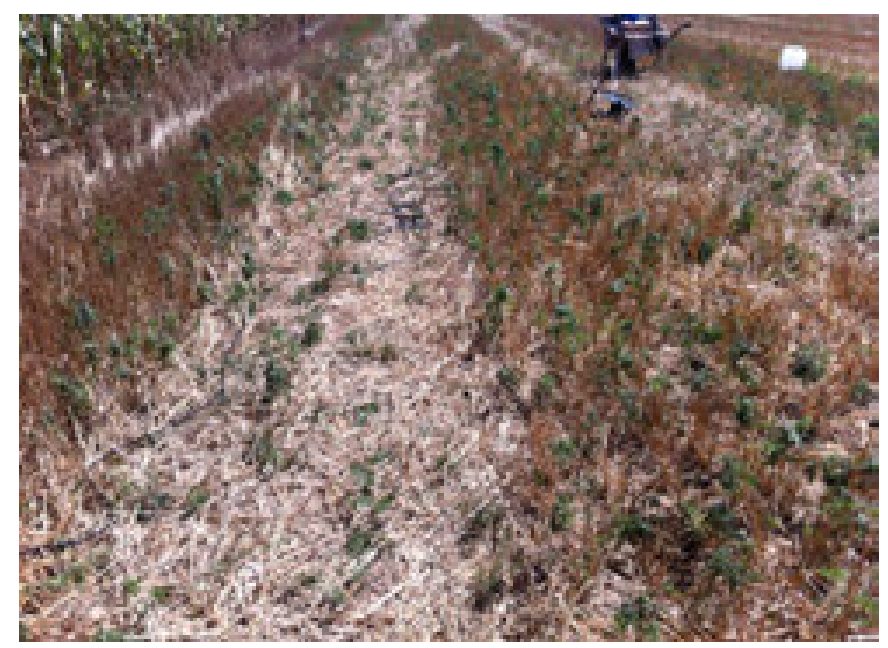

Source: authors, based on research 
On the stems of plants Ambrosia after treatment was determined by the dependence of the specific resistance of plants from the time of operation voltage of $25 \mathrm{kV}$ (Fig. 4).It is observed that the specific resistance of Ambrosia plants comes very fast the to plateau significantly lower value compared to the starting. This phenomenon is favorable because then the electric current passes a more through root hairs/lateral roots than through the soil.In order to avoid problems of higher consumption of energy, must be made a deliberate choice the weather conditions when will be performed treatments, because immediately after the rain resistance of plants grow, and then gradually decreases as the decreasing water content in the soil and therefore the plants.

Figure 4. Diagram of the dependence of the specific resistance from the time of operation voltage $25 \mathrm{kV}$

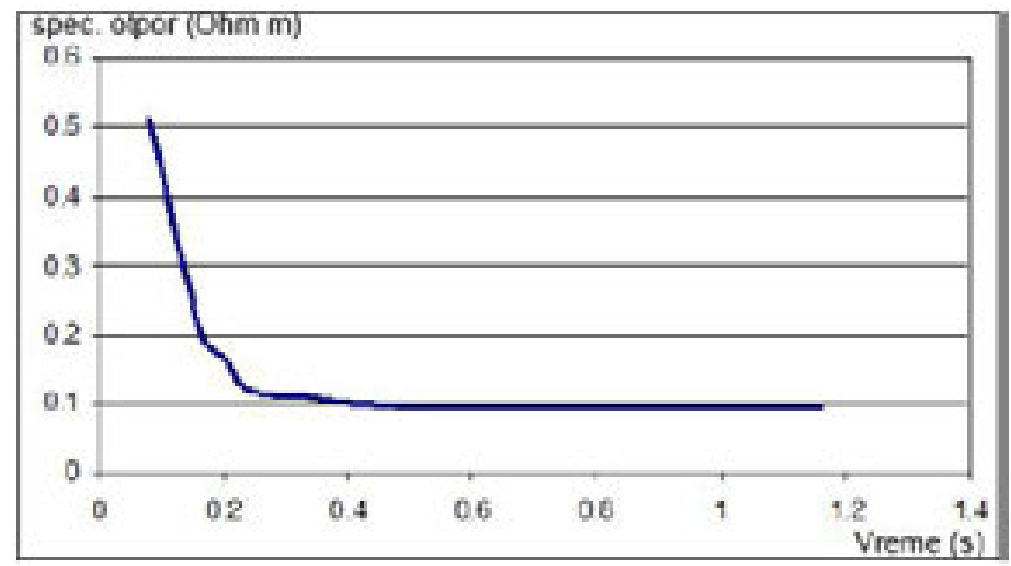

Source: authors, based on research

\section{Conclusion}

In accordance with the all above stated, innovative device for the destruction of ragweed, as compared to known devices of this kind has many advantages, of which the most important are: ease of solutions, simple the power supply high-voltage devices, its efficiency and cost-effectiveness, stability in operation, the output voltage stability, possibility of higher voltages with great safety when handling the device, monitoring and maintenance.Also, there are constructive possibilities of the different versions of the device, the portable hand-held devices to versions for use on a variety of small and large agricultural machines or others.

The authors suggest further research in order to determine the correct parameters of efficiency, cost effectiveness and productivity of this machine compared to other forms of destruction of ragweed on one side and preservation of the environment on the other. 


\section{References}

1. Allard, H.A. (1973): The North American ragweeds and their occurrence in other parts of the world, Science, Vol. 98, pp. 2544-2549

2. Bohren, C., Mermillod, G., Delabays, N. (2006): Common ragweed Ambrosia artemisiifolia in Swityerland development of a nationwide concerted action, Journal of Plant Diseasas and Protection, Vol. 20, pp. 497-503

3. Comtois, P. (1998): Ragweed (Ambrosia sp.): the phoenix of allergophytes. In: SPIEKSEMA, M. (ed.) 1998. Ragweed in Europe. Horsholm, DK: Alk-Abello A/S., p. 3-5

4. Cvijanović, G., Milošević, N., Lalević, B. (2006): The changes of soil biogenity parameters after herbicide treatment, Plant Science, Vol. 43, No 6, Nat. Centre for Agr. Sciences, Sofia, Bulgaria, pp. 558-561

5. Dechamp, C.,Calleja, M., Penel, V., Meon, H. (2002): Progressively earlier onset of pollination of commom ragweed in the Lyon-Bron area over the past 20 years, Rev. francaise allergology et immunology Clinique, Vol. 42, pp. 546-550

6. Diprose, R., Hackan, F., Benson, A. (1978): Weed control by high voltage electric shocks, in Proc 1978. British Crop Protection Conference-Weeds. November. Brigxton, U.K., pp. 443-450.

7. Fumanal, B., Chauvel, B., Bretagnolle, F. (2005): Demography of an allergenic European invansive plant: Ambrosia artemisiifolia, Introduction and Spread of Invasive Species, Berlin, pp. 225-226.

8. Herbološko društvo Srbije (2007): Ambrozija, Beograd, ISBN 86-83979-23-7.

9. IPCC (2007): Climate Change 2007: Impacts, Adaptation, and Vulnerability, Contribution of Working Group II to the Third Assessment Report of the Intergovernmental Panel on Climate Change. M.L. Parry, O.F. Canziani, J.P. Palutikof, P.J. van der Linden, C.E. Hanson, (Ed.), 976, Cambridge University Press, ISBN 9780521 88010-7, Cambridge.

10. Maron, I.L., Vila, M., Bommarco, R., Elmendore, S., Beadsley P. (2004): Rapid evolution of an invasive plant, Ecological Monograph Vol. 7, pp. 261-280

11. Mattsson, B. (1995): Weed Control by Electric Currents - a Review, Swedish University of Agricultural Sciences, Department of Agricultural Engineering, ISSN 00283-0086, ISRN SLU-LT-R-193-SE (Dostupno na: http://pub.epsilon.slu. se/3846/1/mattsson b 091204.pdf)

12. Neikamp, J.W., Johnson, W.G. (2001): Weed management with sulfentrazone and flumioxazin in no-tillage soybean (Glycine ma..L), Crop Protection Vol. 20, pp. 212220

13. Rogers, C.A., Wayne, P. M., Macklin, E.A.,muiilenberg, M.L., Wagner, C.J., Epstein P.R., Bazzaz, F.A. (2006): Interaction of the onset of spring and elevated atmospheric CO2, on ragwees Ambrosia artemisiifolia L. pollen production, Environmental Health perspectives, Vol. 114, No. 6, pp. 865-869. 
14. Slavnić Ž. (1953): Prilog flori našeg Podunavlja, Glasnik biološke sekcije Zagreb Serija II/BT.4-6

15. Stankovic, M. (2012): Electric destroyer of weeds and plants, $3^{\text {rd }}$ International Innovation and Invention Conference "Global Future - Environment and Health", August 2012, Taipei, Republic of China, pages 39-41,ISBN 978-986-86611-1-0.

16. Stankovic, M. (2014): Apparatus for destroying weeds, International Symposium "Environmental and Engineering Aspects for Sustainable Infrastructure" Euro ECO 2014, November 2014, Hanover, Germany, pp. 168-169.

17. Wayne, P., Foster, S., Connoly, J., Bazzaz, F., Epstein, P. (2002): Production of allergnenic pollen by ragweed Ambrosia artemisiifolia L.is increased in $\mathrm{CO}_{2}$ enriched atmospheres, Annals of Allegy and Astma Immunology Vol. 88, No. 3, pp. 279-282 


\title{
EKOLOŠKI ZNAČAJ PRIMENE ELEKTRO-INOVATIVNOG UREĐAJA U PROCESU SUZBIJANJA AMBROSIA ARTEMISIIFOLIA L
}

\author{
Miloš Stankovič́, Marija Cvijanovič́, Vojin Đukićn
}

Rezime

Velike količine aerosola koje se zadržavaju u atmosferi postaju nosači polena. Ambrosia artemisiifolia L ima sposobnost produkcije velike količine polena. S obzirom na veliku adaptibilnost Ambrosia artemisiifolia L pri širenju veliki problem je njeno suzbijanje. $U$ praksi najčešća metoda suzbijanja ambrozije je korišćenje različitih grupa herbicida čime se negativno utiče na životnu sredinu.

Zatoje za cilj rada postavljeno da se istraži efiksanost tretmana biljaka Ambrosia artemisiifolia L naponom preko inovativnog uređaja u fenofazi vegetativnog porasta biljaka posle žetve pšenice. Prvi rezultati su bili vidljivi posle samo 20 minuta, a ukupan broj biljaka u tretmanu bio je uništen posle 5 dana.

Ključne reči: Ambrosia artemisiifolia L, električni napon, struja, otpor biljaka

4 Master Miloš Stanković, doktorand, Alfa BK Univerzitet, Fakultet za finansije, bankarstvo i reviziju, Ulica Palmira Toljatija br. 3, 11000 Novi Beograd, Srbija Telefon: +381 638579805 E-mail: milosstanko@yahoo.com

5 Master, Cvijanović Marija, doktorand, Univerzitet u Beogradu, Poljoprivredni fakultet, Nemanjina ulica br. 6, 11080 Zemun, Srbija, Telefon: +381 6388581085 E-mail: marijacvijanovic@yahoo.com

6 Naučni saradnik, dr Đukić Vojin, Institut za ratarstvo i povrtarstvo, Novi Sad, Ulica Maksima Gorkog br. 30, 21000, Telefon: +381 6482057 51, E-mail: vojin.djukic@ifvens.ns.ac.rs 